\title{
Role of Talent Development Process on Competitive Advantage of Telecommunication Firms in Nairobi City County, Kenya
}

\author{
${ }^{1}$ Charles Kireru, ${ }^{2}$ Kabare Karanja, ${ }^{3}$ G.S Namusonge \\ Jomo Kenya University of Agriculture and Technology, Kenya
}

\begin{abstract}
Talent development can be viewed from literature as the strategic activities and programs that help staff develop and enhance superior and unique skills and competencies to accomplish high level institutional objectives. This resource is an important source of competitiveness especially if the talent is strategic in nature inimitable and rare.For this reasons it is important for a firm to appreciate the unique contributions of investing in talent development and its relationship with competitive advantage. To have the right talent on the right job at the right time defines how telecommunication firms reposition their competitive advantage. Competitive firms should therefore effectively harness the sum of a person's abilities, intrinsic gifts, skills, knowledge, experiences, intelligence, judgment, attitude, character, and drive, ability to learn and to grow potential to positively contribute to creation of an organization competitive advantage. The study sought to establish if there was a positive relationship between talent development processes and competitive advantage. The findings indicated that telecommunication firms have largely invested in talent development plans at (76\%) and Talent methodologies at (62\%) which are key determinants of successful talent development processes. The study therefore recommended that Telecommunication firms should adopt and implement talent development processes as key source of competitive advantage.
\end{abstract}

Keywords: Talent, Development, Competitive, Advantage, Capabilities, Capability Analysis, Telecommunicat ion firms

\section{BACKGROUND OF THE STUdY}

Today, an organizational success is increasingly being associated with identifying, recruiting, developing, and retaining high performers or talented individuals to meet their present and future demands. Available literature confirmed that talent is the most important organizational resource in the $21^{\text {st }}$ century knowledge based sector like in mobile telecommunications. The future competitiveness and prosperity of these firms depends on the capabilities they recruit, develop and retain. The study conducted by the human resource today, (2009), found that $85 \%$ of Human Resource (HR) executives observed that the greatest challenge in workforce management is creating and maintaining organization capability to compete for talent. The study by Price Waterhouse Copper, (2014) also established that organizations that have workforce with the required competencies and skills for executing their programs shape their competitive advantage. Talent development help an organization to identify employees who are capable of playing critical roles, and even multitasking are proffered (Baheshtiffar, 2011). The talent-based theory of the firm holds that talent is a resource that provides sustainable competitive advantage, therefore, a firm should focus primarily on talent and its competitive capabilities (Roberts, 2008 as cited in Moturi, 2013); Kwamboka, 2014). According to the findings of the human capital Institute, (2009) the way organizations manage talent can be a gamechanger as business owners and shareholders comprehend the link between keeping the best talent and achieving competitive edge.

\section{Telecommunication SECTOR}

Telecommunication industry in Kenya has been evolving since early 2000s when major concern was shortage of technical skills to manage and maintain the business. The competitors majorly engaged in poaching of employees with technical skills. According to the telecom regulator, Communication Commission of Kenya, (2014) competition has shifted to specific talent for specific segments of their respective business. Safaricom Kenya Limited bulletin, (2015) reported that its talent acquisition strategy was to attract and retain staff with unique capability. This was meant to develop, implement, and deliver compelling value propositions to consumer segments with a view to sustain its 
competitive advantage. Airtel Networks Limited choice of human capability was to have talent that bring into its business fresh strategy on the fastest growing segments data and mobile money transfer. Currently telecommunication sector is experiencing rapid growth in mobile connections, subscribers and data traffic. It also plays a pivotal role in unlocking socio-economic progress in the country. Many industry sectors are increasingly digitising and mobilising their products and services. A strategic direction aimed at significantly reducing the costs of operation and which provide compelling new frontiers and experiences for ever changing consumer's expectations. Presently key players in telecommunication sector include Safaricom Kenya Limited, Airtel Networks Kenya Limited, and Telkom Kenya (Orange) (CCK, 2013). However the sector because of its significance to economic, social and political contributions has also continued to attract other investors hence fueling the 'War of Talent'.

Study by Waiganjo, (2013) on the linkage between human resource management practices and organization performance found that they contributed to enormous organizational sales growth and profitability. This reinforces the need for organizations to embrace talent development as key human resource management processes practices that defines competitive advantage of organizations. It is deduced from research that as businesses moves to the year 2020, essential to any organization competitive advantage will be the organization ability to manage talent specifically the unique skills and competencies joining the labor market. This will build a formidable competitive platform for competitive advantage which is the focus of this study. According to the literature review Kenya's mobile market has been experiencing rapid growth and is forecast to grow even further over the next five years through the expansion in its mobile data services, particularly mobile banking. As a result, increased competition has emerged as a driver of growth especially with significant changes in the country's telecom industry in form of competition, regulatory framework, leadership, pricing of products and services, innovation, mergers and more recently with new players entering the market and posing significant profit Communications Commission of Kenya, (2015). According to the findings of the study the business environment has forced players in the industry to invest heavily in unique people capabilities to achieve their competitive advantage. The focus of this study was to explore how talent development contributed to this strategy. Porter, (1985) argued that competitive advantage is at the heart of a firm performance in competitive markets while competition is at the core of the success or failure of firms.

\section{Statement of The Problem}

Studies have confirmed that talent development processes have become a major source of business competitive advantage. Additionally sources of competitive advantage have shifted from financial resources to technology resources and now to human talent.Study by PricewaterhouseCoopers, (2014) found that organizations with the right talent for executing their programs have a critical capability that gives them a competitive advantage over others. This is the reason why competition in the telecommunication sector in Kenya has fundamentally shifted to specific talent segments, Communication Commission of Kenya,(2014). The survey by Mckinsey, (2010) revealed that $58 \%$ of the executives reported that building talent capabilities was among their companies' top three priorities, while $90 \%$ placed it among the top ten. Telecommunication firms are a catalyst of improved communication, social inclusion, economic activities and productivity. Unfortunately implementation of talent development processes appears underutilized or disjointed. This denies them much needed skills and competencies which is rare and inimitable. In some instances this has resulted to decreased product innovation speed, customer service delivery, loss of market opportunities, delayed key strategic initiatives and inability to achieve high growth forecast which in overall affect competitive advantage. This paper therefore focuses on establishing the role of talent development processes on competitive advantage.

\section{Methodology}

The study employed a descriptive cross sectional survey design using both quantitative and qualitative approaches. The purpose of the study was to explore and examine specific testable phenomenon. The study assessed the variables based on the current state as reported by the respondents in accordance with, Sekaran, (2003). Open ended questions and content analysis was used in accordance with criteria advocated by Cooper et al, (2006) on qualitative research design. The study focussed on telecommunication firms because of their immense contribution to economic and social progress in Kenya. Additionally the sector is highly competitive and the demand for talent mix is also high. The 
respondents were 377 comprised of the chief executive officers, Director, Divisional and heads of departments, section head and supervisors. This was the critical group as it was knowledgeable about the competition and also the role of talent development processes. They were also aware of the strategic direction of their respective firms hence added the much needed value to the research findings. Semi structured questionnaires and interview schedules were utilized in data collection. The researcher used descriptive statistics which include percentages, means, variances and standard deviations for data presentation while inferential statistics which include correlation analysis and regression analysis, analysis of variance (ANOVA), and chi-square were used to compare the relationships between talent development process and competitive advantage. The results were presented in Pie Charts and tables.

\section{THEORETICAL FRAMEWORK}

According to the resource based theory of the firm talent is a critical resource that any organization should invest to achieve its competitive advantage. It reinforces the need for an organization to invest in talent development to continuously increase value in its people performance. According to the resource-based theory of competitive advantage firms are expected to transform and organise resources into capabilities, which are selectively employed to build competitive advantage that protects their market share, their customer base, or their profit margins (Grant, 1998). Literature on the competitive advantage has taken a shift and it has acknowledged that the internal resources have a crucial role to play in the performance of the organization (Wright \& McMaham, 1992 as cited in Rabii, (2015). The resource based view of the firm gives importance to building unique, hard to imitate and valuable resources as well as a dynamic way to integrate those resources to get success for the organization. According to resource based view competitive advantage is dependent on the valuable, rare and hard to copy resources that reside in the organization and talent is one of those scarce resources. A more recent theory of the firm, the resource based view gives importance to develop and enhance the competency of the employees of the firm through a systematic process of talent acquisition, talent transfer and talent sharing to gain competitive advantage. According to the theory rival firms competes on the basis of the heterogeneity and immobility of their resources and capabilities (Peteraf \& Bergen, 2003). Resources can be physical, human and organizational in nature, and they can be used to implement value-creating strategies.

As suggested by Barney, (1991), resources which are valuable, rare, inimitable, and non-substitutable, have the potential to provide firms with a sustainable competitive advantage. A set of resources that seem to match the above criteria are like talent assets. Firm resources are said to include all assets, capabilities, organizational processes, firm attributes, information, and knowledge, among others controlled by a firm. They enable the firm to conceive of and implement strategies that improve efficiency (doing things right) and effectiveness (doing the right things). Bersin integrated talent management model brings this theory in focus of the human capital resource which includes training, capabilities, experience, judgment, intelligence, relationships and insight of individual managers and workers in a firm. The resource-based view of the firm is presently being touted as an alternative theory of competitive advantage to that developed by Porter, (2004). Resources based view theory posits that a firm achieves sustainable competitive advantage by developing resources, which add unique or rare value, and which can't easily be copied by others. Wright, et al. (1994) point out that talent can be a source of competitive advantage because it meets the criteria for being a source of sustainable competitive advantage. Gratton, (1997) observed that most companies believe that human talent rather than financial or technological resources determine competitive advantage that can best be achieved through better talent utilization while Newbert, (2008) posited that there is a strong linkage between talent and competitive advantage.

According to Barney, (1991), competitive advantage is recognized as the level of exceptional performance that a firm attains when it devises and implements value-enhancing strategy that is concurrently being followed by any existing or possible competitors. In addition these firms are either incapable or reluctant to reproduce the benefits of this strategy. Rabii, (2015) noted that the resource based theory of the firm hypothesize that talent is the only resource of firms which may provide basis for sustainable competitive advantage. Therefore, organizations should focus on talent and the capabilities derived from it. This forms the basis for the need to invest in talent development processes. Heinmen \& Collen, (2011) opined that it is only talent development practice which gives an organization sustained competitive advantage in the market. Resource Based View (RBV) of 
Barney (1991) suggests that sustainable competitive advantage is attainable when firms have a human resource pool which cannot be imitated or substituted by rivals. Hence firms should constantly evaluate their workforce to ensure that they have the right people with the right skills and competencies in the right places to ensure sustained competitive advantage. When this is not the case, firms should make-up for the shortfall by acquiring talent needed from the labor market. The theory maintained that the major part of any firm's strength or weakness stem from the caliber of the people employed and their capabilities.

The significance of resource-based theory can be attributed to a number of factors. First it concern what is arguably the most central topic in the field of strategic management, and why some firms outperform others while they are in the same sector. In addition, it addressed a number of other core topics, such as firm heterogeneity, growth, and diversification. Talent development produces skills and competencies which should be valuable, rare, and inimitable and have no substitute to positively influence competitive advantage. The theory treats enterprises as potential creators of value-added capabilities and the underlying organizational competencies involves viewing assets and resources of the firm from talent based perspective. As depicted in the conceptual model development of unique capabilities is prerequisite for unlocking employee's potential to deliver superior returns which have a positive impact on competitive advantage.

\section{CONCEPTUAL FramewORK}

The general objective of this study was to explore the role of talent development processes on competitive advantage of telecommunication firms in Nairobi City County, Kenya.

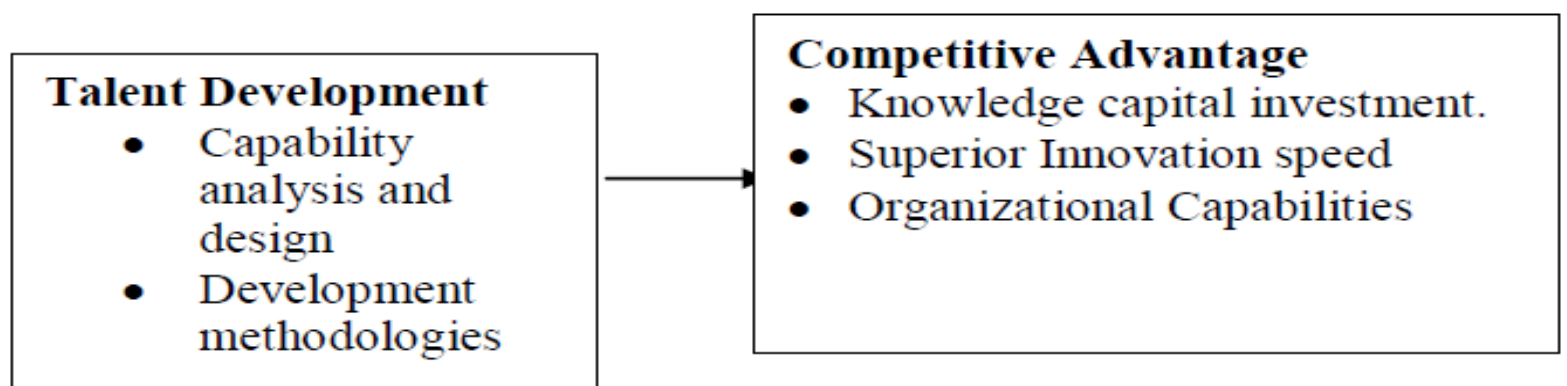

\section{Independent}

Variables

\section{Dependent}

Figure1. Conceptual Framework

\section{Talent Development Processes}

Talent development can be viewed from literature as the activities and programs that help staff develop superior and unique skills and competencies to accomplish high level institutional and divisional goals. They also help staff to grow personally and professionally and prepare them for advancement in the firms or beyond it. The focus of this study will be based on the key determinant of talent development namely on capabilities analysis and design and development methods. Organization through HR Professional forecast systematically an organization's talent demand and supply in future. Talent need analysis should be done carefully and still consider all factors that influence it, for example organizational strategy, culture, inventory of HR capabilities, competitive environment and labor market. To recruit sufficient and suitable staff with talent, an organization must conduct human resource planning which is concerned with labor statistics, quality of the personnel and with their deployment throughout the organization (Cole, 2011). Talent capability development is a learning experience in that it seeks a relatively permanent change in an individual that will improve ability to perform on the job. Learning is the process by which a person acquires new knowledge, skills, and capabilities. This process encompasses all activities as a way to increase employee's competency to fulfill business demand. The significance of talent development in organizations is reinforced by the fact that high quality leadership development programs and formal succession management programs results in superior business results (Bernthal \& Wellins, 2006). There have been arguments that effective career development programs are not only important in improving talent "skills and preparing them to emerging organizational challenges but also in gaining talent" commitment to the organization. In other words, career development programs should aim at enhancing talent's ability to manage current and future responsibilities. In addition, increasingly tight 
labor markets make succession management a business imperative and put pressure on organizations to identify and accelerate the development of future leaders from within (Busine \& Watt, 2005).

Given this pressure, the enduring organization needs to have an effective succession management policy in place, with a particular focus on the continuity of key specialists and leaders (Stone, 2002). According to Chapman, (2009), the most effective way to develop people is to enable learning and personal development to take place. To identify learning and training needs of the organisation, a learning needs analysis should be carried out. The areas and methods include analysis of business and human capital plans; surveys; performance and development reviews; job, role and competency analysis; describing the content of jobs and roles by reference to key activities and outcomes. It also deals with defining the performance standards required in terms of quantity and output; and defining the knowledge, skills and competencies needed to perform the job in order to meet the performance standards. Firms can develop and enhance the quality of the current employees by providing comprehensive training and development. Research indicates that investments in staff capacity building in areas such as, problem-solving, decision making, teamwork, and interpersonal relations result in beneficial firm level outcomes (Rohan Singh, 2012). It also has a significant effect on employee performance. Firms can develop and enhance the quality of the current employees by providing comprehensive career development programs and career path. Indeed, research indicates that investments in training employee in problem-solving, teamwork and interpersonal relations result in beneficial firm level outcomes (Singh, 2012) in a rare organization. Russel, (2012) found that training was correlated with sales volumes per employee and store image in a sample of retail outlet stores. Effective career training programs are systematic and continuous. In other words, staff development must be viewed as a long term process not just an infrequent and/or haphazard event (Ng'ang'a, 2013). Assessments of employee and organizational needs as well as business strategies should be conducted and then used in selecting development methods and participants (Kadian, 2010). Development programs that are consistent with employee and organizational goals and needs and fit with the business strategy will deliver the firm competitive advantage. (Rohan, 2012).

Brandy \& Spence, (2009) add that a defining characteristic of globalization is the rapid development and use of technology, not only to speed up and reduce cost of production and services, but also to speed up and reduce the cost of business and trade. It is important for firms to emphasize career training and development to all levels of management and the employees at the shop floor (Ivancevich, 2010). According to Waweru, (2007) new employees almost invariably need some form of development before taking on their new jobs, while the older employees need development to keep them abreast with technological development and ethics. The Federation of Kenya Employers Report, (2010) while supporting this view for advocated for productivity training which it defined as a standard program on improvements on labor efficiency, work methods, cost income ratio, and assets utilization among other areas. The foregoing concern echoes the need to realign the skills of employees with the immediate objectives and goals of the organization. Organizational factors such as organizational policy, management style and levels of technology may also be crucial in determining the efforts employees put forth to enhance productivity-a balance should be struck since extremes on either side may lead to dissatisfaction and result to employee turnover (Luthans, 2008).

According to Garavan, Carbery \& Rock (2012), talent development is significantly under-developed and under-researched concept. However, a number of researches seem to agree that it is better to develop talents in-house rather than trying to acquire them from outside the organization. This is because talent or high potential in one organization may not be a talent/high potential in another organization (Burkus \& Osula, 2011). They also contend that an organization should create deliberate practice opportunities, and that training programs should be open to all employees. Garavan, Carbery, \& Rock (2012) present four future important areas in the field of talent development as; the new focus on strategic talent, where talent development processes need to be integrated with business strategy. The trend of differentiation of talent development, shifting the responsibility and control over talent development from the organization to the individual - who to a higher extent will self-manage his/her development, which in turn will place more value on communities of practice as a way of developing individuals in group contexts. Furthermore, and a just-in-time talent development process is suggested, since there will be a continuous demand for talent development combined with the need for a mixed strategy, which blends different sources of learning along the lines of the 70-20-10 model. Armstrong, (2010) opined that the fundamental aim of talent development is to enhance resource 
capability in accordance with the belief that human capital of an organization is the major source of competitive advantage. It is therefore about ensuring that the right quality people are available to meet present and future needs of an organization. This is achieved by producing a coherent and comprehensive framework for developing people. Indeed, some objectives of talent development are to develop intellectual capital and promote organizational, team and individual learning by creating a learning culture - an environment in which employees are encouraged to learn and develop and in which knowledge is managed systematically.

\section{EMPIRICAL REVIEW}

Kenani, (2011) established that there seem to be an urgent need for increasing scientific knowledge and skills of employees at geothermal companies in Kenya. Human resource management needs to put more emphasis on the productive development and use of people in the company to collectively achieve the organization's strategic business objectives. The study found that geothermal companies were challenged to strive to work towards improved balance between labor supply and demand, a better trained workforce and increased employability of the workforce (Kenani, 2011). Azara and Syed, (2013) study on staff development and the organization performance, revealed a significant and positive association between capability development and the organization performance and competitive advantage. The study used qualitative and quantitative research designs while questionnaires were the main data collection instruments. Poorhosseinzader et al., (2012) used cross sectional study done on Malaysian Multinational companies found a positive and significant relationship between developing talents and the success of the companies with correlation of 0.728 and $p$ value of 0.000 at 0.05 level of significance level. The recent studies by the Economic Forum and Boston Consulting Group (2011) and the manpower Group (2011) showed that the shortage of talent problem is truly global: it affect wide variety of positions in many regions and countries of the World. This study found that Telecommunication firms are heavily using capability analysis and development methodologies to manage talent shortages and training needs.

\section{FINDINGS AND Discussion}

The study sought to establish the role of talent development process on competitive advantage of telecommunication firms in Nairobi City County, Kenya. The results presented under this section are based on data collected from the field. According to the literature review an organization develop and invest in talent in order to produce optimal value for its customers than its rivals by gaining competitive advantage.

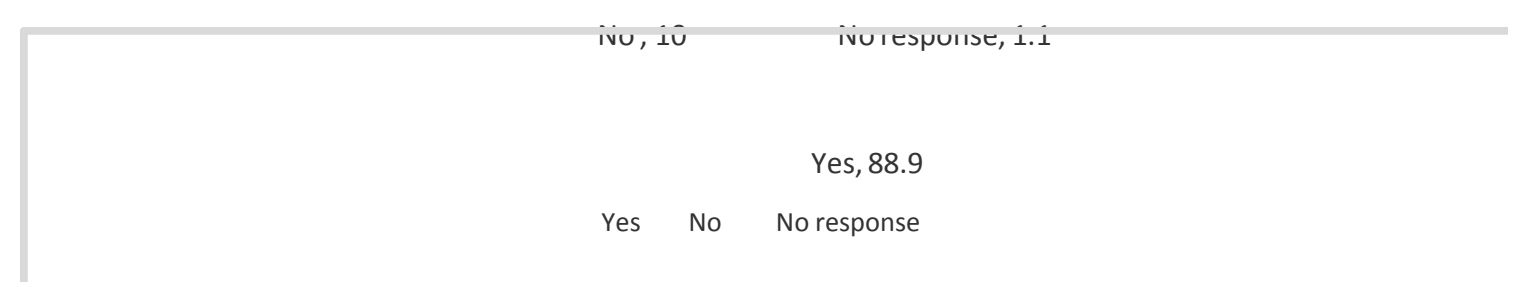

Figure1. Talent development Processes and organization competitive advantage

The findings indicated that $330(88.9 \%)$ of respondents agreed that talent development processes play a major role is driving the competitive advantage of the telecommunication firms in Nairobi City County, Kenya

\subsection{Relationship Between Talent Development Processes and Organization Competitive Advantage}

The study sought to establish if there was a positive relationship between talent development processes and organization competitive advantage. The results are as shown in figure 2.below: -

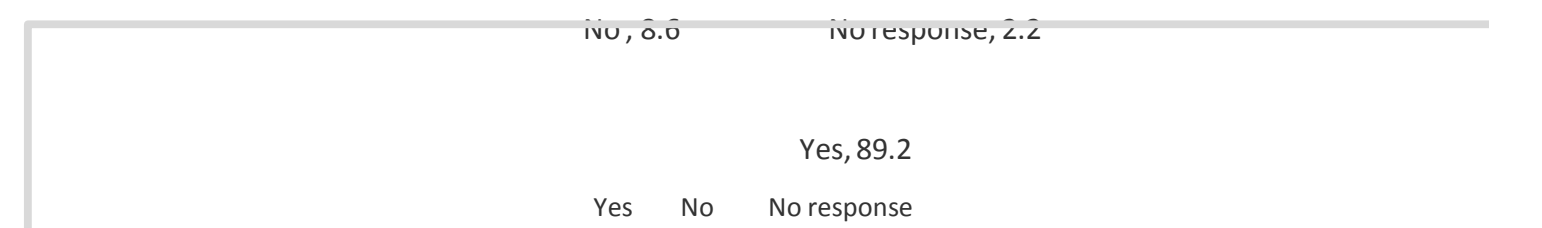

Figure2. Relationship between Talent Development Processes and Organization Competitive Advantage 
Role of Talent Development Process on Competitive Advantage of Telecommunication Firms in Nairobi City County, Kenya

The findings indicated that $331(89.2 \%)$ of the respondents agreed that there is a significant relationship between talent development processes and organization competitive advantage. In this case the researcher concluded that telecommunication firms in Nairobi City County Kenya should focus on talent development processes.

\subsection{Talent Development Plan}

According to the findings 281(75.7\%) of the respondents agreed that telecommunication firms have a talent development plan in place. The researcher therefore concludes that telecommunication firms in Nairobi City County have talent development plan that guides talent development.

Table1: Talent development Processes and Competitive Advantage

\begin{tabular}{|c|c|c|c|c|c|c|c|c|c|c|c|}
\hline & & 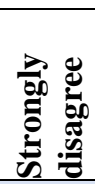 & 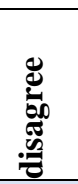 & $\frac{0}{0}$ & 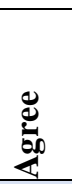 & 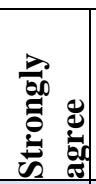 & & $\begin{array}{l}\mathbf{N} \\
\mathbf{R}\end{array}$ & Mn & Stdv & $X^{2}$ \\
\hline \multirow{2}{*}{$\begin{array}{l}\text { There is significant rel } \\
\text { ationship between tal } \\
\text { ent development and } \\
\text { competitive advantage }\end{array}$} & $\mathbf{F}$ & 26 & 38 & 39 & 109 & 157 & 266 & 2 & 3.902 & 1.254 & \multirow{2}{*}{$\begin{array}{l}X^{2}=75.32 \\
p=.000\end{array}$} \\
\hline & $\%$ & 7.0 & 10.2 & 10.5 & 29.4 & 42.3 & 71.7 & .5 & & & \\
\hline \multirow[b]{2}{*}{$\begin{array}{l}\text { The company under ta } \\
\text { kes talent development } \\
\text { assessment need anal } \\
\text { ysis to determine the } \\
\text { gaps identified in staff } \\
\text { capabilities. }\end{array}$} & $\mathbf{F}$ & 35 & 38 & 66 & 117 & 109 & 226 & 6 & 3.622 & 1.273 & \multirow[b]{2}{*}{$\begin{array}{l}X^{2}=81.507 \\
p=.000\end{array}$} \\
\hline & $\%$ & 9.4 & 10.2 & 17.8 & 31.5 & 29.4 & 60.9 & 1.6 & & & \\
\hline \multirow{2}{*}{$\begin{array}{l}\text { The company has a } \\
\text { talent development des } \\
\text { ign for guiding talent } \\
\text { development. }\end{array}$} & $\mathbf{F}$ & 29 & 42 & 61 & 94 & 130 & 224 & 15 & 3.714 & 1.290 & \multirow{2}{*}{$\begin{array}{l}X^{2}=94.309 \\
p=.000\end{array}$} \\
\hline & $\%$ & 7.8 & 11.3 & 16.4 & 25.3 & 35.0 & 60.3 & 4.0 & & & \\
\hline \multirow{2}{*}{$\begin{array}{l}\text { There is different types } \\
\text { of talent development } \\
\text { methods that guides } \\
\text { each profession }\end{array}$} & $\mathbf{F}$ & 30 & 27 & 74 & 101 & 130 & 231 & 9 & 3.757 & 1.246 & \multirow{2}{*}{$\begin{array}{l}X^{2}=110.459 \\
p=.000\end{array}$} \\
\hline & $\%$ & 8.1 & 7.3 & 19.9 & 27.2 & 35.0 & 62.2 & 2.4 & & & \\
\hline \multirow{2}{*}{$\begin{array}{l}\text { Talent development } \\
\text { contributes to the deve } \\
\text { lopment of the organi } \\
\text { zation capabilities in } \\
\text { our organization }\end{array}$} & $\mathbf{F}$ & 17 & 32 & 56 & 126 & 131 & 257 & 9 & 4.000 & 2.390 & \multirow{2}{*}{$\begin{array}{l}X^{2}=156.821, \\
p=.000\end{array}$} \\
\hline & $\%$ & 4.6 & 8.6 & 15.1 & 34.0 & 35.3 & 69.3 & 2.5 & & & \\
\hline \multirow{2}{*}{$\begin{array}{l}\text { There is a significant } \\
\text { relationship between } \\
\text { talent development and } \\
\text { development of supe } \\
\text { rior innovation }\end{array}$} & $\mathbf{F}$ & 22 & 24 & 67 & 102 & 147 & 249 & 9 & 3.906 & 1.183 & \multirow{2}{*}{$\begin{array}{l}X^{2}=156.812 \\
p=.000\end{array}$} \\
\hline & $\%$ & 5.9 & 6.5 & 18.1 & 27.5 & 39.6 & 67.1 & 2.4 & & & \\
\hline \multirow{2}{*}{$\begin{array}{l}\text { Talent development is } \\
\text { linked to the organi } \\
\text { zation investment in } \\
\text { knowledge capi tal }\end{array}$} & $\mathbf{F}$ & 30 & 27 & 50 & 120 & 136 & 256 & 8 & 3.840 & 1.238 & \multirow{2}{*}{$\begin{array}{l}X^{2}=146.986, \\
p=.000\end{array}$} \\
\hline & $\%$ & 8.1 & 7.3 & 13.5 & 32.3 & 36.7 & 69 & 2.2 & & & \\
\hline \multirow{2}{*}{$\begin{array}{l}\text { There is a talent deve } \\
\text { lopment strategy and } \\
\text { policy framework in } \\
\text { place in our organizat } \\
\text { ion. }\end{array}$} & $\mathbf{F}$ & 37 & 27 & 73 & 101 & 124 & 225 & 9 & 3.685 & 1.291 & \multirow{2}{*}{$\begin{array}{l}X^{2}=93.856 \\
p=.000\end{array}$} \\
\hline & $\%$ & 10.0 & 7.3 & 19.7 & 27.2 & 33.4 & 60.6 & 2.4 & & & \\
\hline
\end{tabular}

The study sought to establish the role of talent development process on competitive advantage of telecommunication firms in Nairobi City County Kenya. Talent development is viewed from literature as the activities and programs that help staff develop superior and unique skills and competencies to accomplish high level institutional and divisional goals. According to the findings $88.9 \%$ of respondents agreed that talent development process contribute to competitive advantage. Another $75.7 \%$ of the respondents agreed that telecommunication firms have talent development plans that guide talent development activities while $60.9 \%$ agreed that telecommunication firms in Nairobi City 
County Kenya undertake talent development assessment and Talent need analysis to determine the gaps identified with a view to strengthen their staff capabilities. In addition, $60.3 \%$ of the respondents indicated that telecommunication firms have talent development design for guiding talent development while $62.2 \%$ of the respondents concurred that there are different types of talent development methods that guides talent development.

The findings also confirmed that $69.3 \%$ of the respondents agreed that talent development process strengthen organization capabilities of telecommunication firms while $67.1 \%$ agreed that talent development contributes to superior innovation and speed. Further analysis indicated that $69 \%$ of the respondents agreed that Telecommunication firms heavily invest in knowledge capital which is a determinant of competitive advantage. In addition, $60.6 \%$ of the respondents agreed that talent development strategy and policy framework is critical processes that contribute to competitive advantage of telecommunication firms.

\subsection{Role of Talent Development process on Competitive Advantage}

The overall model for the construct talent development process was tested. The findings in Table 2 showed that the coefficient of determination $\mathrm{R}$ Square $=0.498$ and $\mathrm{R}=.706$ at 0.05 at significance level. The coefficient of determination indicated that $49.8 \%$ of the variation on competitive advantage is explained by talent development process. This confirmed that there is a strong positive correlation coefficient between talent development process and competitive advantage. The tests of Beta coefficient indicated that there is significant relationship between talent developments process and competitive advantage which is positive. The significance coefficient of 0.00 is significantly greater than zero since the t-statistics 3.326 is greater than 2 . This demonstrated that talent development process has a positive effect on competitive advantage.

Table2. Model Summary Influence Talent Development Process on Competitive Advantage

\begin{tabular}{|c|c|c|c|c|c|c|c|c|c|c|}
\hline \multicolumn{11}{|c|}{ Model Summary } \\
\hline \multirow[t]{2}{*}{ Model } & \multirow[t]{2}{*}{$\mathbf{R}$} & \multirow{2}{*}{$\begin{array}{l}\text { R } \\
\text { Square }\end{array}$} & \multicolumn{7}{|c|}{ Adjusted RStd. Error of Change Statistics } & \multirow{2}{*}{\begin{tabular}{|l} 
Durbin-Watson \\
e
\end{tabular}} \\
\hline & & & Square & the Estimate & \begin{tabular}{|l}
$\mathbf{R}$ Square \\
Change
\end{tabular} & F Change & df1 & df2 & $\begin{array}{l}\text { Sig. F } \\
\text { Change }\end{array}$ & \\
\hline 1 & $.706^{\mathrm{a}}$ & .498 & .497 & .165524 & .498 & 366.382 & 1 & 369 & .000 & 1.877 \\
\hline
\end{tabular}

\section{$49.8 \%$}

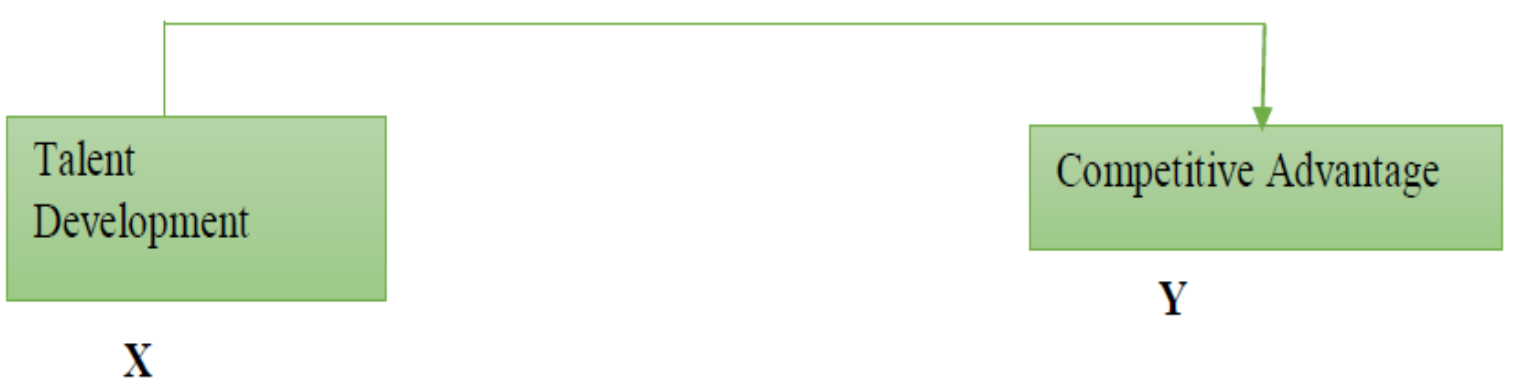

Figure2. Influence Talent Development on Competitive Advantage

This view is also supported by a study by Karemu, et al (2014), on critical analysis of talent management on medical employee's retention in public hospitals in Kenya, which indicated that talent development strategies impacted positively on the retention of doctors and nurses at Kenyatta National hospital in Kenya. The studied variables were career development, compensation and benefits attractiveness, nature of work climate and levels of training and development. The data obtained from the study indicated that talent development strategies impacts positively on the retention of doctors and nurses at Kenyatta national hospital in Kenya. Availability of career development opportunities showed the highest significant relationship with retention $(\beta=0.614$, pvalue $=0.019$ ). A unit increase in career development opportunities would lead to effects in retention of with the findings of the current study which shows career development playing the greatest role in employee retention and talent management. 
Role of Talent Development Process on Competitive Advantage of Telecommunication Firms in Nairobi City County, Kenya

Table3. Influence ANOVA Talent Development Process on Competitive Advantage

\begin{tabular}{|c|c|c|c|c|c|c|}
\hline ANOV & & & & & & \\
\hline Model & & Sum of Squares & df & Mean Square & $\mathbf{F}$ & Sig. \\
\hline & Regression & 10.038 & 1 & 10.038 & 366.382 & $.000^{\mathrm{b}}$ \\
\hline 1 & Residual & 10.110 & 369 & .027 & & \\
\hline & Total & 20.148 & 370 & & & \\
\hline a. Depe & dent Variable & apetitive Advantag & & & & \\
\hline b. Predi & ors: (Constar & lent Development & ocess & & & \\
\hline
\end{tabular}

The results of Analysis of variance (ANOVA) for regression coefficients are as shown below, table 4.23. The analysis results indicated that the significance of $F$ statistics was 366.382 which is less than 0.05. This implied that there was a significant positive relationship between talent development process and competitive advantage.

Table4. Coefficients of Influence Talent Development on Competitive Advantage

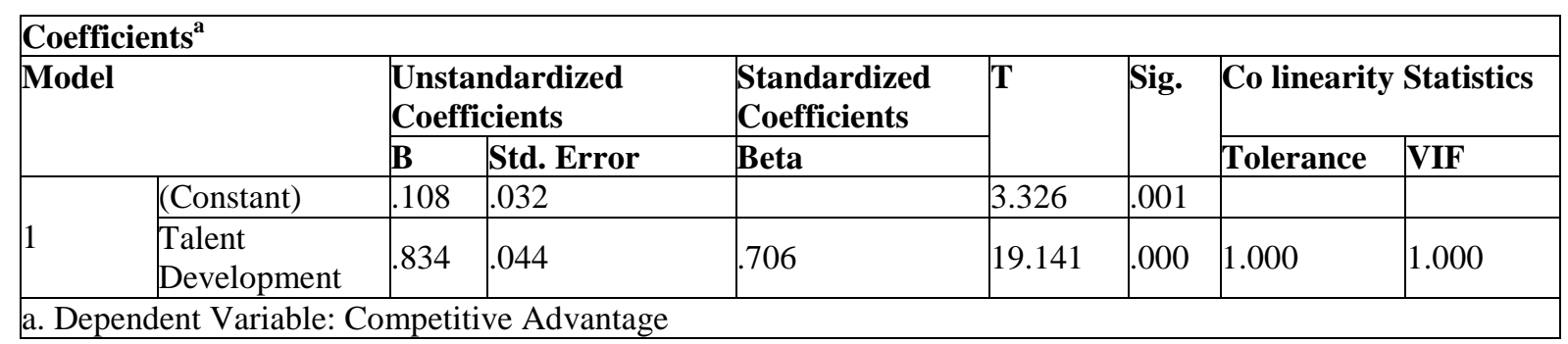

According to table $4, \beta$ showed that change in talent development process by one-unit effect competitive advantage by 0.706 . After that value of $t$ shows the significance or insignificance of independent variable upon dependent variable. When the value of $t>2$, results are significant. Here the value of $t$ is 19.141which showed the significance of talent development on competitive advantage is positive. In this case the null hypothesis is accepted. The overall findings showed that on average respondents mean>3.5 who supported the statements related to talent development process and competitive advantage. The overall model for the construct talent development process was tested. According to the analysis as per Table 4.14; indicates the coefficient of determination $\mathrm{R}$ Square= 0.498 and $\mathrm{R}=.706$ at 0.05 at significance level. The coefficient of determination showed that a unit changes in talent development cause $49.8 \%$ change of competitive advantage. This showed that there exists a strong positive correlation coefficient between talent development process and competitive advantage. The test of Beta coefficient shows that the significant relationship between talent developments process on competitive advantage is positive. The significance coefficient of 0.00 is significantly greater than zero since the t-statistics 3.326 is greater than 2 , which demonstrates that talent development process has a strong positive impact on competitive advantage of telecommunication firms in Nairobi City County Kenya

\section{SUMmary}

According to the findings talent development process has a positive role towards competitive advantage of the telecommunication firms in Nairobi City County in Kenya. In addition, it is evident that there is high level commitment to talent development audit. This is significant as it enabled them to keep on identifying talent gaps to fill to meet the changing demands of the business. The findings also confirmed that these organizations make use talent development design for guiding talent development programs for their talented workers and invest in development of organization capabilities, and knowledge capital which correlates to development of superior innovation. These approaches contributed to their competitive advantage. The existence of talent development strategy and policy framework is main in driving talent development framework to ensure it deliver optimal contributions to organization competitive advantage. Overall talent development process contributed $49.5 \%$ of telecommunication competitive advantage.

\section{RECOMMENDATIONS}

The study recommended that telecommunication firms should invest in talent development processes, talent development plans, capability analysis talent development designs and methodologies. This will 
assure them of continuous supply of rare resources found in human skills and competencies. In addition leadership should invest in talent audits to ensure skills and competencies gaps are indentified and timely filled. The study established that these processes are directly linked with determinant of competitive advantage; organization capabilities, knowledge capital, superior innovation and speed.

\section{REFERENCES}

[1] Armstrong, M. (2007). A Handbook of Human Resource Management Practice. Sterling: Kogan Page

[2] Azara,S. \& Mohammed ,A.K.(2013). Employee training and Organizational Performance: Mediation by employee Performance. Interdisciplinary Journal of Contemporary Research in Business.5 (4) pp 490-503.

[3] Baheshtiffar, M. (2011). Role of Career Competencies in Organization. European. Journal of Economics Finance and Administrative Sciences, 42(1) pp 201221.

[4] Barney, J. (1991). Firm resources and sustained competitive advantage. Journal of Management. 17(1): 99-120.

[5] Bhatla, N. \& Pandey, K., (2014). The impact of HR issues in retail sector in emerging market with special reference to luck now. Journal of Business and Management, February, 16(1), pp. pp-01-07.

[6] Burkus, D., \&Osula, B. (2011). Faulty Intel in the War for Talent: Replacing the Assumptions of Talent Management with Evidence-based Strategies. Journal of Business Studies Quarterly, Vol.3, No.2, 1-9.

[7] Busine, M., \& Watt, B. (2005). Succession management. Trends and current practice. Asia Pacific Journal of Human Resources, 43(2). 225-237.

[8] Cappelli, P \& Singh, H (1992). Integrating strategic human resources and strategic management. Research Frontiers in Industrial Relations and Human Resources, ed

[9] D Lewin, O Mitchell and P Scheller, Industrial Relations Research Association, Madison, Win Cooper, D. and Schindler, P. (2006). Business Research Methods. $7^{\text {th }}$ Edition, New York: Irwin/McGraw Hill

[10] Rabii.F. (2015). Talent Management as Source of Competitive Advantage. Asian Economic and Social Society. ISSM (P) 2309-8895) Vol. 5, 2015

[11] Garavan, T. N., Carbery, R., \& Rock, A. (2012). Mapping talent development: definition, scope and architecture. European Journal of Training and Development. 1, 5-24.

[12] Gratton, L. (1997). HR Strategy. People management. 3(15). 22-27

[13] Hatum, A. (2010). Next Generation Talent Management: Talent Management to Survive the Turmoil. Palgrave Macmillan.

[14] Kahinde James Sunday (2012). Talent management effect on organization performance. Journal of management research. 4(2).

[15] Kenani, D.M. (2011). Strategic options to human resource challenges in geothermal operations in Kenya. Proceedings, Kenya Geothermal Conference 2011 Kenyatta International Conference Centre, Nairobi.

[16] Mckinsey \& Company (2010) Building Organizational Capabilities: Mckinsey Global Survey Results.

[17] Price Water House Coopers (2012). Talent management in Africa: The CEO mindset in Africa PWC. July Issue. Retrieved 30th April 2013 from http://www.pwc. com/ke/en/pdf/theafricabusiness-agenda-2012-talent agenda.pdf.

[18] Ng'ang'a, R. (2013). The Relationship between Training and Development in state owned Corporations.

[19] Ng'ethe, J.M.; Namusonge, G.S. \& Iravo, M A. (2012). Influence of Leadership Style on Academic Staff Retention in Public Universities in Kenya. International Journal of Business and Social Science. 3(21); November 2012.

[20] Price Waterhouse Coopers (2014). Thought Leadership Report. Powering Strategic Initiatives. 
Role of Talent Development Process on Competitive Advantage of Telecommunication Firms in Nairobi City County, Kenya

[21] Vaiman, V. (2010). Managing talent of non-traditional knowledge workers opportunities, Challenges, and trends. Vaiman, V. (Ed.), Talent Management of Knowledge Employees: Embracing Non-traditional Workforce, Palgrave Macmillan, Basingstoke. 1-22.

[22] Waiganjo Esther, \& Mukhulu E. \& Kagiri J. (2013). Effects of competitive strategies on the Relationship between Strategic Human Resource Management and Firms Performance of Kenya Corporate Organizations.

\section{AUTHOR's BIOGRAPHY}

Charles Kireru is a seasoned human resource practitioner/consultant in human resource management, policy formulation and implementation. He has a valuable mix of $20+$ years experience in senior hr management level with dynamic and reputable firms in aviation, maritime manufacturing, security, education, construction and building, hospital and health and county government in kenya. $\mathrm{He}$ has been a part time lecturer with jkuat, laikipia university, kenya methodist university and a member of institute of human resources management, international labor \&amp; employment relations association and consultant in management with favor world international. he possesses higher national diploma in human resources management, bachelor of arts degree in social sciences; masters of science in human resources management and currently pursuing Phd in HRM with jomo kenyatta university of agriculture and technology.

Dr. Kabare Karanja is currently serving as director, jkuat, centre for governance and integrated trade, in westlands campus, a senior lecturer in management studies in the fields of human resource management, strategic management, business planning and development, marketing management and research, organizational behavior, organizational change and development. He has also served as adjunct faculty member in management studies in the many institutions of higher learning both at undergraduate and post graduate levels since 2004.

Dr. Gregory Simiyu Namusonge is professor and consultant in the school of human resource development, jomo kenyatta university of agriculture and technology. He holds a Phd in entrepreneurship, master of business administration (MBA) and bachelor of education in business and economics (First class honours). He is an educator, curriculum expert, external examiner, mentor, advisor, and supervisor to bachelors, masters and Phd degree level students at university level national, regional and international level.

Citation: Charles, Kireru et al. "Role of Talent Development Process on Competitive Advantage of Telecommunication Firms In Nairobi City County, Kenya." International Journal of Managerial Studies and Research (IJMSR), vol 5, no. 8, 2017, pp. 1-11. doi:http://dx.doi.org/10.20431/2349-0349.0508001.

Copyright: (๑) 2017 Authors. This is an open-access article distributed under the terms of the Creative Commons Attribution License, which permits unrestricted use, distribution, and reproduction in any medium, provided the original author and source are credited. 